\title{
The Effect of Environmental Corporate Social Responsibility (CSR) Disclosure to Investor Behavior: Empirical Study from Indonesia Capital Market
}

\author{
Marsdenia \\ Universitas Indonesia \\ Depok, Indonesia \\ Marsdenia@ui.ac.id
}

\begin{abstract}
The purpose of this study is to investigate the effect of environmental CSR Disclosure to investor behavior. Proxy of investor behavior is Cummulative Abnormal Returns (CAR). Motivation of study is inconclusive result of effect of environmental CSR disclosure to investor behavior. Main contribution of this research is new approach to measure environmental CSR disclosure by using content analysis of GRI (Global Report Initiative) 4 method. Sources of data from listed company of Indonesias' capital market which acquired from software such as data stream, Eicon database and yahoo.finance. Method of research is quantitative approach and regression model, by processing of pool cross section data collected consisting of simple and multivariate. This Research finding is environmental CSR Disclosure has insignificant effect to investor behavior. Implication of this research to motivates corporates to increase environmental CSR activities in order to save the world, humanity and doing green business. Significancy of the research is to promote green accounting, so accounting can participate in protecting environment in order to elevate the the quality of life .
\end{abstract}

Keywords-environmental CSR disclosure; investor behavior; content analysis; GRI 4; green business

\section{INTRODUCTION}

Accountant role in the digital era are very crucial as people can acquired information from various sources as we called it that we are in the big data era. The most important thing of accountant role is to give an information to help or give benefits to user of financial statement in making a proper decision either as an investor or as a creditor or as a government agency. Investor make decision in response of information from financial statement we called it investor behavior (Kong et al., 2011). This paper will focused on investor behavior in the effect of environmental CSR disclosure in the companies' annual reports..

There are so many previous researches on the investor behavior in the meaning of value relevant of information from financial statement. Ragab and Omran (2006) used return on investment (ROI) approach and pricing model to measure investor behavior in response of financial information from financial statement. Riahi, Belkaoui (1994) concluded that equity value of firm has a linear association with some accounting measures and this results is indifference among firms. Ball and Brown (1968) and Collins et al., (1989) stated that valuation model on the basis of accounting information, also showed that equity value has an association with earnings accounting. This results consistent with Landsman (1986) and Barth (1991) and Shevlin (1991) concluded balance sheet measurement or book value dan earnings have an association (Landsman, 1986; Barth, 1991; Shevlin, 1991). Ragab and Omran (2006) concluded capital market need other information sources as a complementary to accounting information in order to achieved efficiency in information

Previous research are focused on USA and other developed countries capital market. So, this paper try to investigate gap research of capital market in the emerging countries such as Indonesia. Eventhough, some previous research have focused on value relevant of accounting information from non USA capital market such as in the Egypt (Amir et al, 1993; Harris et al, 1994; Barth and Clink 1996, Chan and seow, 1996; Graham and King, 1998). Ragab dan Omran (2006) have a consistent findings which stated that capital market need other sources of information as a complementary of information accounting from financial statements..

Research on value relevant of information in related to environmental corporate social responsibility disclosure in the notes to financial statement still have inconclusive conclusions (Ambec and Lanoie, 2008; Berchichi and Kiy, 2007). Meanwhile, Firms will have a motivation to invest in environmental aspect if this kind of investment will increase their wealth/equity. Unfortunately, Facts stated it is difficult to find that environmental investment will increase return on investment. In contrast, Cordeiro and Tewari (2015) find positive reaction of investor on environmental corporate social responsibility (CSR) disclosure in the annual reports announcements.

There are two main contribution of this paper, first, give alternative proxy to measure environmental CSR disclosure by content analysis approach. Second, enrichment of literature on emerging countries' capital market especially Asean countries with focused topic on investor behavior to environmental CSR 
disclosure. The main objective of this study ia to investigate investor behavior on environmental CSR disclosure.

Next, this paper will consists of some sub parts, part 2 will discuss literature review regarding environmental CSR disclosure and investor behavior. Then, part 3 explained about research method of this paper, discussed about data dan sample selection criteria and research model to answer research questions. Part 4 is results of this study and discussion of the last Part 5 conclusion of the paper and suggestions for future research.

\section{ENVIRONMENTAL CSR DISCLOSURE}

\section{A. Investor Behavior}

Landsman (1986) and Barth (1991) and Shevlin (1991) concluded balance sheet measurement or book value dan earnings have an association (Landsman, 1986; Barth, 1991; Shevlin, 1991). Ragab and Omran (2006) concluded capital market need other information sources as a complementary to accounting information in order to achieved information efficiency. Previous research are focused on USA and other developed country capital market

\section{B. Environmental CSR Disclosure}

Based on stakeholder Theory, this paper will give explanation logical background how environmental CSR disclosure influence investor behavior. If firms disclosed their environmental CSR (Kong et al., 2011; Franch, 2011), so asymetric information on investor or stakeholder side will decrease. By decreasing asymetric information stakeholders expected to firms, consequently will increase investor response and stakeholder relationship with firms will be better. Investor is one of the main stakeholders of the firms, so potential investor will give good response to firms, either buy or sold the share/stocks of those firms (You et al., 2012)

Based on study literature on investor behavior and environmental CSR disclosure, this paper have a following hypothese:

\section{H 0 : environmental CSR disclosure has an influenced to investor behavior}

\section{RESEARCH METHOD}

\section{A. Data and Sample}

In order to do a testing to the hypotheses, This research used secondary data from Indonesia capital market, populations are all of the firms for period 2010-2014. Sample for this research consists of manufacturing company amounting to 44 companies and total observation data is 244 year observations. Paper used GRI 4 approach to select sampel those meet criteria of the research. There are ten (10) keyword to measure weather firms partisipation in environmental investmen (Tabel 1)

\begin{tabular}{|c|c|}
\hline & $\begin{array}{l}\text { TABLE } 1: \quad \text { LIST } \quad \text { KEYWORD } \\
\text { ENVIRONMENTAL } \\
\end{array}$ \\
\hline 1 & recycled \\
\hline 2 & energy consumption \\
\hline 3 & energy intensity \\
\hline 4 & water source \\
\hline 5 & biodiversity \\
\hline 6 & emissions / effluents \\
\hline 7 & waste \\
\hline 8 & spills \\
\hline 9 & environmental impacts \\
\hline 10 & packaging materials \\
\hline
\end{tabular}

Based on above keyword, this paper identified the firm have an environmental CSR disclosure if disclose at least one of the above ten keyword. This study used variable dummy, it means that 1 if annual report company has at least one keyword through content analysis approach and 0 is otherwise.

\section{B. Research Model}

- This research to tested the effect of environmental CSR disclosure to investor behavior

- Proxy to measure environmental CSR disclosure from content analysis approach, as discussed before

- Investor behavior measurement is using cumulative abnormal return. Cumulative abnormal return figure from formula abnormal return is difference between expected return and actual return of investor.

\section{RESULTS AND DISCUSSIONS}

Result of regress all of the data in the table 2.

TABLE 2 : REGRESSION RESULT

Dependent Variable: Y

Method: Panel Least Squares

Sample: 20102014

Periods included: 5

Cross-sections included: 44

Total panel (balanced) observations: 220

\begin{tabular}{lllll}
\multicolumn{1}{r}{ Variable } & \multicolumn{1}{c}{ Coefficient } & \multicolumn{1}{c}{ Std. Error } & t-Statistic & Prob. \\
& & & & \\
C & 0.124796 & 0.058183 & 2.144894 & 0.0331 \\
X & -0.009921 & 0.070937 & -0.139859 & 0.8889 \\
& & & & \\
R-squared & 0.000090 & Mean dependent var & 0.118121 \\
Adjusted R-squared & -0.004497 & S.D. dependent var & 0.492590 \\
S.E. of regression & 0.493696 & Akaike info criterion & 1.435257 \\
Sum squared resid & 53.13446 & Schwarz criterion & 1.466108 \\
Log likelihood & -155.8783 & Hannan-Quinn criter. & 1.447716 \\
F-statistic & 0.019561 & Durbin-Watson stat & & 2.068086 \\
Prob(F-statistic) & 0.888901 & &
\end{tabular}

Table 2 showed that there is negative effect of variable independent to variable dependent. Independent variable is 
environmental CSR disclosure, and dependent variable is investor behavior as proxy as CAR (Cummulative Abnormal Returns). Coefficient -0.009921 explained that there is negative effect of environmental CSR disclosure to investor behavior. It means that if environmental CSR disclosure exist or increase in annual reports of company, investor response to this ind of disclosure is decrease in response. On the other words, there is decreasing of investor behavior by proxy of cummulative abnormal returns $r$ of companies' share/stock in the capital market, so differences between actual return and expected return smaller.

If we focused on ability of independent variable to explained varians of dependent variable, too small. The figure only 0.00090 , it means that cumulative abnormal return varians only explained by environmental CSR disclosure for about $0.09 \%$ and $99.91 \%$ explained by other factors. So in the next research we should input more variables in the model of reserach.

We can ignores durbin watson test, since the equation model only use single independent variable. Unfortunately Prob (F-statistic) > Prob, 0.888901>0.0331, it means that there are no significant effect of environmental CSR disclosure, since previous study results is still inconclusive, may be this is the main reason of insignificancy results. Additionally, in this study has some limitations which give future research suc as, small sample of company where is only 44 companies meet he criteria sample of research. An also period of study coverage too short onli 5 years, future research better more than 5 years, let say 10 to 20 years. The last limitations is proxy to measure environmental CSR disclosure, it would be comprehensive if the identification using data published by reputable institution/agency like in the USA and UK (You et al., 2012).

TABLE 3: REGRESSION RESULT WITH-EFFECT SPECIFICATION

Sample: 20102014

Periods included: 5

Cross-sections included: 44

Total panel (balanced) observations: 220

\begin{tabular}{lllll}
\hline \hline Variable & Coefficient & Std. Error & t-Statistic & Prob. \\
\hline \hline $\mathrm{C}$ & 0.032374 & 0.075149 & 0.430802 & 0.6672 \\
$\mathrm{X}$ & 0.127462 & 0.100127 & 1.272999 & 0.2047 \\
\hline \hline \multicolumn{7}{l}{ Effects Specification } \\
\hline \hline
\end{tabular}

Cross-section fixed (dummy variables)

Period fixed (dummy variables)

\begin{tabular}{|c|c|c|c|}
\hline R-squared & 0.213993 & Mean dependent var & 0.118121 \\
\hline \multirow{2}{*}{\multicolumn{4}{|c|}{$\begin{array}{l}\text { Adjusted } \\
\text { squared }\end{array}$}} \\
\hline & -0.006641 & S.D. dependent var & 0.492590 \\
\hline regression & 0.494223 & Akaike info criterion & 1.621830 \\
\hline \\
\hline $\begin{array}{l}\text { resid } \\
\text { Log }\end{array}$ & 41.76781 & Schwarz criterion & 2.377684 \\
\hline $\begin{array}{l}\text { Log } \\
\text { likelihood }\end{array}$ & -129.4013 & Hannan-Quinn criter. & 1.927064 \\
\hline \multirow{2}{*}{$\begin{array}{l}\text { F-statistic } \\
\text { Prob(F- } \\
\text { statistic) }\end{array}$} & 0.969902 & Durbin-Watson stat & 2.520407 \\
\hline & 0.535154 & & \\
\hline
\end{tabular}

Table 3 is regression result with effect specifications. The effect still insignificant but in the different sign. The regression result showed that effect of independent variable to dependent variable is in the positive sign. It means that cumulative abnormal returns as proxy of investor behavior will increase in line with increasing or existence of environmental CSR disclosure in the company annual reports. Consequencies of increasing in cummulative abnormal returns are the bigger of the differences between actual return and expected return of share/stocks those companies. This result support the Facts stated in the introduction, it is difficult to find that environmental investment will increase return on investment. In contrast, Cordeiro and Tewari (2015) find positive reaction of investor on environmental corporate social responsibility (CSR) disclosure in the annual reports announcements.

Ability of independent variable to explained varians of dependent variable (cummulative abnormal returns) is more if it compare to table II. The $\mathrm{R}$ square is $21.39 \%$, meaning environmental CSR disclosure in the annual report can explained $21.39 \%$ varians of CAR, the rest $78,61 \%$ will explained by other variable excluded in the model of research.

There are some limitations of this research that give contribution to the results/findings that stated insignificant effect of environmental CSR disclosure to investor behavior which proxy CAR. Actually there a huge proxy for investor behavior such as Buy and Hold (BHD), Actual returns, Actual Returns. It will be comprehensive study if used some proxy for investor behavior.

\section{CONCLUSIONS AND SUGGESTIONS}

Since the results is insignificant effect of environment CSR disclosure to investor behavior, this study give a signal that if we including some factors in the model of research imay be we can get different result. Inconclusive conclusions of previous study on this topic will give opportunity for future researchs.

Suggestions for future research are using different measurement for investor behavior and environmental CSR disclosure, using more companies as sample and long period research coverage. And also add more variable inddependent in the model, hopefully ability to explained independent variable of dependent variable will increase, since this study models' $\mathrm{R}$ square is too small.

\section{ACKNOWLEDGMENT}

Thank you very much to Vocational Program University of Indonesia Accounting department, so this paper complete and finally submit to this conference. Hopefully this is a process learning for author.

\section{REFERENCES}

[1] Ambec, S., \& Lanoie, P. (2008). Does it pay to be green? A systematic overview, Academy of Mangement Perspectives, 22 (2), pp. 45-62.

[2] Amir, E., Harris, T. and Venuti, E. (1993). A Comparison of the valuerelevance of US versus Non-US GAAP accounting measures using form 20-F reconciliation. Journal of Accounting Research, Vol. 31, pp. 230264. 
[3] Ball, R. And Brown, P. (1968). An empirical evaluation of accounting income numbers. Journal of Accounting Research, Vol 6, pp. 159-178.

[4] Baraber, B and Lyon, J. (1997). Detecting long-run abnormal stock returns: the empirical power and specification of test statistics. Journal of Financial Economics, Vol: 43 No. 2 pp. 341-372

[5] Barth, M. (1991). Relative measurement errors among altenative pension assets and liability measures. The Accounting Review, Vol. 66 No. 3, pp. 433-463.

[6] ---------, and Clinch, G. (1996). International accounting difference and their relation to share prices: evidence from UK, Australian and canadian Firms, Contemporary Accounting Research, Vol. 13, pp 135170.

[7] Berchicci, L., and King, A. (2007). Postcards from edge: a review of the business and environment literature. Chapter 11 Annuals of the Academy Management.

[8] Brav, A. and Gompers, P. (1997). Myth or reality? The long run underperformance of initial oublic offerings evidence from venture capital and non-venture capital-backed companies . Journal of Finance, vol. 52 No. 5: 1791-1822.

[9] Chan, JP, and Seow, GS. (1996). The association between stock returns and foreign GAAP earnings versus adjusted to US GAAP . Journal of Accounting and Economics, Vol. 21: 139-158. $b$

[10] Collins, D. Kothari, S. And Rayburn, J. (1989). An analysis of intertemporal and cross-sectional determination of earnings respons coefficient. Journal of Accounting and Economics, Vol. 11, pp.143-181.

[11] Cordeiro, J.,7 Tewari M. (2015). Firm characteristic, industry context, and investor reactions to environmental CSR: A stakeholder theory approach. Journal business Ethucs Vo; 130: 833-849.

[12] Delmas, M, \& Toffel, M. W. (2011). Institutional pressurees and organizational characteristic: Implications for environmental strategy. In Oxford handbook of Business and the environment, p. 229-247. Oxford: Oxford University Press.

[13] Dyah et al., (2012). Pengaruh pengungkapan tanggungjawab sosial dan lingkungan perusahaan terhadap ERC, dengan ukuran perusahaan dan leverage sebagai variabel kontrol. Jurnal. Atmajaya Universitas

[14] Easton, P. And Harris, T. (1991). Earning as explanatory variable for returns. Journal of Accounting Research, Vol 29 : 19-39.

[15] Graham, R. And King, R (1998). The relation of firm market with book value and residual accounting earnings in six Asian countries. Working Paper. Oregon State University Corvaliss, OR

[16] Greenwald, B., \& Stiglitz, J. (1990). Asymetric Infirmation and the new theory of the firm: Financial co

[17] Kothari, S. And Zimmerman, J. (1995), Price and return models . Journal of Accounting and Economics, Vol 20: 155-192.

[18] Landsman, W.. (1966). An empirical investigation of pensiun and fund property rights. The Accounting Review, Vol. 61 No. 4, October: 662691.

[19] Lyon, J. Barber, B and Tsai, C. (1999). Improved method for tests of long-run abnormal stosk returns, Journal of Finance, Vol. 54 No. 1: 165201

[20] Ragab dan Omran, A. (2006). Accounting information, value relevance, and investor behavior in the Egyptian. Review of Accounting Finance, Vol. 5 No. 3: 279-297.

[21] Riahi-Belkoui, A. (1994). Net value added as an explanatory variable returns . Managerial Finance, Vol. 20 No. 9: 55-64.

[22] Sayekti dan Wondabio. (2007) Pengaruh CSR disclosure terhadap ERC . SNA tahun 15 di Unsoed, Purwokerto.

[23] Shevlin, T. (1991). The Valuation of R \& D firms with R \& D limited parntership. The Accounting Review, Vol. 65 No. 1: 1-21

[24] Itami H. (1987). Mobilizing Invisible Assets. Harvard University Press: Cambridge, MA

[25] Kohli AK, Jaworski BJ, Kumar A. (1993). MARKOR: a measure of market orientation. Journal of Marketing Research 30 (November): 467477.
[26] Yin, Q. J. \& Cheng, C. S. A. (2004). Earnings management of profit firms and loss firms in response to tax rate reductions. Review of Accounting \& Finance, 3, 67-93. 